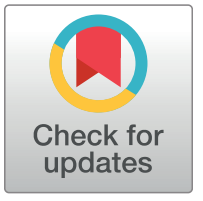

\section{G openaccess}

Citation: Sylvestre TF, Cavalcante RdS, da Silva JdF, Paniago AMM, Weber SS, Pauletti BA, et al. (2018) Serological proteomic biomarkers to identify Paracoccidioides species and risk of relapse. PLoS ONE 13(8): e0202804. https://doi. org/10.1371/journal.pone.0202804

Editor: Kirsten Nielsen, University of Minnesota, UNITED STATES

Received: June 21, 2018

Accepted: August 9, 2018

Published: August 29, 2018

Copyright: ๑ 2018 Sylvestre et al. This is an open access article distributed under the terms of the Creative Commons Attribution License, which permits unrestricted use, distribution, and reproduction in any medium, provided the original author and source are credited.

Data Availability Statement: All relevant data are within the paper and its Supporting Information file.

Funding: The authors received no specific funding for this work.

Competing interests: The authors have declared that no competing interests exist.

RESEARCH ARTICLE

\title{
Serological proteomic biomarkers to identify Paracoccidioides species and risk of relapse
}

\author{
Tatiane Fernanda Sylvestre ${ }^{1 *}$, Ricardo de Souza Cavalcante ${ }^{1}$, Julhiany de Fátima da \\ Silva ${ }^{1}$, Anamaria Mello Miranda Paniago ${ }^{2}$, Simone Schneider Weber ${ }^{2,3}$, Bianca \\ Alves Pauletti ${ }^{4}$, Lídia Raquel de Carvalho ${ }^{5}$, Lucilene Delazari dos Santos ${ }^{6}$, Rinaldo \\ Poncio Mendes ${ }^{1}$
}

1 Universidade Estadual Paulista (UNESP), Faculdade de Medicina de Botucatu, Botucatu, São Paulo, Brazil, 2 Universidade Federal de Mato Grosso do Sul (UFMS), Faculdade de Medicina, Campo Grande, Brazil, 3 Instituto de Ciências Exatas e Tecnologia (ICET), Universidade Federal do Amazonas (UFAM), Itacoatiara, Brazil, 4 Laboratório Nacional de Biociências, CNPEM, Campinas, São Paulo, Brazil, 5 Universidade Estadual Paulista (UNESP), Instituto de Biociência de Botucatu, Botucatu, São Paulo, Brazil, 6 Centro de Estudos de Venenos e Animais Peçonhentos (CEVAP), UNESP, Botucatu, São Paulo, Brazil

* thaty_sylvestre@ hotmail.com

\section{Abstract}

The sensitivity of the double agar gel immunodiffusion test is about $90 \%$ in patients with untreated paracoccidioidomycosis (PCM), but it is much lower in cases of relapse. In addition, serum from patients with PCM caused by Paracoccidioides lutzii, frequent in the Midwest region of Brazil, do not react with the classical antigen obtained from $\mathrm{Pb} B-339$. These findings showed the need for alternative diagnostic methods, such as biological markers through proteomics. The aim of this study was to identify biomarkers for the safe identification of PCM relapse and specific proteins that could distinguish infections caused by Paracoccidioides brasiliensis from those produced by Paracoccidioides lutzii. Proteomic analysis was performed in serum from 9 patients with PCM caused by $P$. brasiliensis, with and without relapse, from 4 patients with PCM produced by $P$. lutzii, and from 3 healthy controls. The comparative evaluation of the 29 identified plasma proteins suggested that the presence of the immunoglobulin (Ig) alpha-2 chain $\mathrm{C}$ region and the absence of Ig heavy chain V-III TIL indicate infection by $P$. Iutzii. In addition, the absence of complement factor B protein might be a predictor of relapse. The evaluation of these proteins in a higher number of patients should be carried out in order to validate these findings.

\section{Introduction}

Paracoccidioidomycosis (PCM) is a systemic disease caused by thermodimorphic fungi of the Paracoccidioides brasiliensis complex-P. brasiliensis and P. lutzii [1]. PCM is confined to Latin America and is endemic in an area that extends from Mexico to Argentina [2], with a higher incidence in Brazil, where it is frequently diagnosed in the state of São Paulo [3]. The recent identification of PCM caused by $P$. lutzii explained the low frequency of positive serological tests in these patients when the $\mathrm{Pb}$ B-339 antigen, a P. brasiliensis fungus, was used. This 
finding demonstrated the difficulty of performing both the serological diagnosis of PCM by $P$. lutzii and the serological follow-up during its treatment [4-6].

Despite the effective treatment of PCM caused by P. brasiliensis, quiescent fungi can lead to relapse, usually about five years after discontinuation of the treatment, in both acute/subacute and chronic forms [7]. Evaluations performed at admission have not been able to identify cases that progress to relapse. In addition, the recent identification of $P$. lutzii has required studies to identify PCM caused by every species. That study revealed that the sensitivity of the double immunodiffusion agar gel reaction (DID) was only $45 \%$ at relapse, and that the enzyme-linked immunosorbent assay (ELISA) was slightly better (65\%), but with a sensitivity level much lower than that observed in treatment-naive patients [7].

The studies that used a proteomic approach focused on the identification of $P$. brasiliensis proteins [8-10] and P. lutzii [11]; however, they did not evaluate serum proteins from PCM patients.

The aim of this study was to use a proteomic approach to identify proteins that could differentiate infections caused by $P$. brasiliensis from those produced by $P$. lutzii, as well as to identify a biomarker that could foresee patients who are prone to relapse.

\section{Subjects and methods}

\section{Patients}

A prospective paracoccidioidomycosis control surveillance has been performed since 1988 at the Clinical Mycology Outpatient Service of the Tropical Diseases Area of the Faculdade de Medicina de Botucatu-São Paulo State University (UNESP) and since 1980 at the Infectious and Parasitic Diseases Service of the Faculdade de Medicina-Federal University of Mato Grosso do Sul (UFMS). The data have been stored initially in specifically prepared file cards and then transferred to a computer system. Serum samples from these patients were appropriately stocked, frozen and stored in a freezer at $-80^{\circ} \mathrm{C}$.

A retrospective study was performed in 13 PCM-patients, characterized as either confirmed or probable cases regarding Mendes criteria [12], and 3 healthy controls from Botucatu region. Treatment compliance, avoidance and/or stopping alcohol intake and smoking were reiterated to all patients at all outpatient visits

\section{Inclusion criteria}

A. PCM cases caused by $\boldsymbol{P}$. brasiliensis. Confirmed cases were characterized by the presence of a suggestive clinical picture and the identification of typical Paracoccidioides sp. yeast forms in one or more clinical materials, with or without a positive double agar gel immunodiffusion test (DID) using an antigen prepared from $\mathrm{Pb}$ B-339 [13]. We also included probable cases, characterized by the presence of a suggestive clinical picture and antibodies detected by $\mathrm{DID}$, using antigen prepared from $\mathrm{Pb} \mathrm{B}-339$, but without a mycological confirmation. These characterizations were made upon the patient's admission to the Faculdade de Medicina de Botucatu (UNESP), as to Mendes et al. criteria [12].

B. PCM cases caused by $\boldsymbol{P}$. lutzii. We included confirmed cases, which were characterized by the presence of a suggestive clinical picture, the identification of typical forms of the Paracoccidioides sp yeast phase in one or more clinical materials, the absence of the serum antibodies by DID using the $\mathrm{Pb}$ B-339 antigen, and the identification of serum antibodies by DID using cell-free antigen (CFA) obtained from EPM-208 strain of P. lutzii, performed at the Federal University of São Paulo, Zoilo Pires de Camargo Service [6].

This characterization was carried out at patient admission to the Infectious and Parasitic Diseases Service of the Faculdade de Medicina-Federal University of Mato Grosso do Sul (UFMS). 
Exclusion criteria. The presence of other systemic diseases of infectious, inflammatory, or neoplastic origin as co-morbidities, pregnancy and lactation were considered exclusion criteria.

Classification of clinical forms. The clinical forms and severity of each patient were classified by the specialist in infectious diseases who attended these patients, regarding Mendes (1994) [14] and Mendes et al. (2017) [12].

Appropriate treatment and definition of relapse. The treatment was considered appropriate when the patient progressed until reaching the apparent cure. The apparent cure includes a clinical cure (the disappearance of the symptomatology characterizing the disease, and normalized erythrocyte sedimentation rate), as well as a serological cure (persistent negative DID for one year under consolidation antifungal treatment), radiological cure (the disappearance of compatible lung lesions upon activity, substituted by residual lesions, such as fibrosis and emphysema) and, finally, the maintenance of these conditions for two years after discontinuation of the antifungal compound [12].

Relapse was characterized by the resurgence of PCM-compatible signs and symptoms in initially confirmed or probable cases associated with the identification of typical forms of the yeast phase of $P$. brasiliensis in any clinical specimen and/or the identification of specific antibodies by DID. Then, these types of relapse were clinical and mycological, clinical and serological or clinical, mycological and serological, depending on the laboratory results. Patients presenting suggestive clinical picture, but with negative mycological and serological tests, were considered relapsed cases only when they reached apparent cure following cotrimoxazole (CMX) treatment. This relapse was considered of the clinical type. None of the relapsed cases presented any laboratory evidence of disease of another etiology.

Study groups and research design. Group 1 (G1): consisted of five patients from the Botucatu region, with PCM caused by P. brasiliensis; these individuals presented a late relapse;

Group 2 (G2): consisted of four patients from the Midwest region of Brazil, with PCM caused by $P$. lutzii;

Group 3 (G3): was comprised of four patients from the Botucatu region, with PCM caused by $P$. brasiliensis; these individuals did not relapse; and

Group 4 (G4): consisted of three healthy individuals living in the Botucatu region; they were blood donors from the Blood Center of Botucatu.

The evaluation of patients from G1, G2, and G3 was performed on admission, before the introduction of the antifungal treatment. Table 1 presents the characterization data of the patients regarding gender, age, clinical form, and diagnosis and of the healthy controls, as to gender and age.

\section{Methods}

Blood sampling and serum storage. Patients' and individuals' serum samples from the $\mathrm{G} 1, \mathrm{G} 3$, and G4 groups were drawn and stored in a freezer at $-80^{\circ} \mathrm{C}$ at the Tropical Diseases Research Laboratory-Medical Mycology, Faculdade de Medicina de Botucatu-São Paulo State University (UNESP). The sera of G2 were assigned by Dr. Anamaria Mello Miranda Paniago, from the Infectious and Parasitic Diseases Service of the Faculdade de Medicina-Federal University of Mato Grosso do Sul (UFMS).

\section{Proteomic analysis}

Proteomic analysis was performed in four steps: protein quantification, protein digestion in solution, peptide sequencing by mass spectrometry (MS), and data analysis to identify the proteins. 
Table 1. Characterization of study groups according to gender, age and clinical form.

\begin{tabular}{|c|c|c|c|c|c|c|}
\hline \multirow[t]{2}{*}{ Groups } & \multirow[t]{2}{*}{ Individual } & \multirow[t]{2}{*}{ Gender } & \multirow[t]{2}{*}{ Clinical form } & \multirow{2}{*}{$\begin{array}{c}\text { Age (years) } \\
\text { before treatment }\end{array}$} & \multicolumn{2}{|c|}{ Diagnosis } \\
\hline & & & & & before treatment & at relapse \\
\hline \multirow{5}{*}{$\begin{array}{c}\text { Group 1 } \\
\text { Patients with } \\
\text { P. brasiliensis and relapse }\end{array}$} & 01 & M & $\mathrm{CF}$ & 42 & $\mathrm{MD} / \mathrm{CP}$ sputum & Clinical / MD \\
\hline & 02 & M & $\mathrm{CF}$ & 50 & HP oral mucosa & Clinical-cure with $\mathrm{CMX}^{*}$ \\
\hline & 03 & M & $\mathrm{CF}$ & 34 & CP sputum & Clinical-cure with CMX \\
\hline & 04 & $\mathrm{~F}$ & $\mathrm{AF}$ & 15 & CP lymph node & Clinical / HP lymph node \\
\hline & 05 & $\mathrm{~F}$ & $\mathrm{AF}$ & 85 & CP linfonodo / HP skin & Clinical / HP skin \\
\hline \multirow{4}{*}{$\begin{array}{c}\text { Group } 2 \\
\text { Patients with } \\
\text { P. lutzii }\end{array}$} & 06 & M & $\mathrm{CF}$ & 53 & MD oral mucosa & - \\
\hline & 07 & M & $\mathrm{CF}$ & 43 & HP oral mucosa & - \\
\hline & 08 & M & $\mathrm{CF}$ & 38 & HP oral mucosa & - \\
\hline & 09 & M & $\mathrm{CF}$ & 53 & HP skin / MD sputum & - \\
\hline \multirow{4}{*}{$\begin{array}{c}\text { Group 3 } \\
\text { Patients with } \\
\text { P. brasiliensis, without relapse }\end{array}$} & 10 & M & $\mathrm{CF}$ & 54 & MD sputum / HP oral mucosa & - \\
\hline & 11 & M & $\mathrm{CF}$ & 55 & HP oral mucosa & - \\
\hline & 12 & M & $\mathrm{AF}$ & 38 & HP lymph node & - \\
\hline & 13 & $\mathrm{M}$ & $\mathrm{AF}$ & 17 & MD / HP skin & - \\
\hline \multirow{3}{*}{$\begin{array}{c}\text { Group } 4 \\
\text { Healthy individuals }\end{array}$} & 14 & M & - & 35 & - & - \\
\hline & 15 & $\mathrm{M}$ & - & 29 & - & - \\
\hline & 16 & $\mathrm{~F}$ & - & 42 & - & - \\
\hline
\end{tabular}

CF- chronic clinical form; AF-acute/subacute clinical form; M- male; F- female; P. brasiliensis_Paracoccidioidesbrasiliensis; P. lutzii-Paracoccidioideslutzii; MDmycological direct; CP sputum-cytopathologic sputum; HP oral mucosa-histopathology of oral mucosa; MDoral mucosa-Mycological direct of oralmucosa; CP lymph node-cytopathologic node; HP skin-histopathological skin; HP lymph node-histopathology of lymph node and CMX-cotrimoxazole * patient presented a strongly positive ELISA test for the diagnosis of PCM relapse.

Protein auantification. The proteins present in the serum samples were quantitated in triplicate by Bradford's method [15] (BioRad®); Protein Assay, cod. 500-0001), with bovine albumin (BSA) as the standard protein.

Protein digestion in solution. The samples were submitted to enzymatic digestion in solution. To this end, the reduction and alkylation steps were initiated using $10 \mathrm{mM}$ dithiothreitol (DTT) and $45 \mathrm{mM}$ iodoacetamide (IAA), respectively, both of which were solubilized in $50 \mathrm{mM}$ ammonium bicarbonate solution. Then, the samples were submitted to hydrolysis in the presence of the enzyme trypsin (Promega Corporation, Madison, WI, USA) at a concentration of 1:50 (enzyme: substrate), solubilized in $50 \mathrm{mM}$ ammonium bicarbonate buffer $(\mathrm{pH}$ 7.8), which occurred for 18 hours; it was interrupted with the addition of $1 \%(\mathrm{v} / \mathrm{v})$ formic acid to the sample volume. The samples were then desalted using Sep-Pak Vac C18 (Waters Corporation, Milford, MA, USA) cartridges, reduced in SpeedVac ${ }^{\mathrm{TM}}$ (ThermoFisher Scientific, Waltham, MA) and maintained at $4^{\circ} \mathrm{C}$ until the time of analysis by MS.

Peptide sequencing by MS. MS analysis was performed at the National Laboratory of Biosciences (LNBio), located at the National Center for Research in Energy and Materials (CNPEM) in Campinas, São Paulo State, Brazil. An aliquot (4.5 $\mu \mathrm{L})$ of digested proteins was injected by an analytic column (C18 $1.7 \mu \mathrm{m}$ BEH 130) (100 $\mu \mathrm{m} \times 100 \mathrm{~mm})$ RP-UPLC (nanoAcquity UPLC; WatersCorporation), coupled with nano-electrospray tandem MS on a Q-Tof Premier API mass spectrometer (MicroMass; Waters Corporation) at a flow rate of $600 \mathrm{~nL} /$ minute. A trapping column (Symmetry C18; $180 \mu \mathrm{m} \times 20 \mathrm{~mm}$ ) was used for sample desalting at a flow rate of $5 \mu \mathrm{L} /$ minute over 2 minutes. The gradient was $2 \%-90 \%$ acetonitrile in $0.1 \%$ formic acid over 45 minutes. The instrument was operated in MS-positive mode, with data continuum acquisition occurring from $\mathrm{m} / \mathrm{z} 100-2,000 \mathrm{Da}$ at a scan rate of 1 second, and an interscan delay of 0.1 seconds [16]. 
Data analysis for protein identification. The MS files were processed using the Mascot Distiller v.2.3.2.0 program (2009; Matrix Science Ltd., London, UK), along with the Mascot Server v.2.3.01.0 program (Matrix Science Ltd.).The following parameters were used: cleavage lost by trypsin; the fixed modification of carbamidomethylation; the variable modification of methionine oxidation; 0.1 Da mass tolerance for MS; and 0.1 Da mass tolerance for MSMS. Searches were conducted using the NCBI database (Homo sapien taxonomy, 33,695,097 sequences; available at http://www.ncbi.nlm.nih.gov/protein/?term=homo\%20sapiens) containing 92,180 sequences and 36,693,332 residues. For protein quantification, the data were submitted to the Scaffold Q + analysis program (version 3.4.5; Proteome Software, Portland, OR, USA) obtaining normalized spectral count values for each identified protein.

After identification, the proteins were characterized according to the main functions they performed, and the primary proteins in each group were subsequently characterized. The networks of protein interactions against the differentially expressed proteins were analyzed using the STRING 10 tool.

\section{Statistical analysis}

The results were presented as the mean and standard deviation. Student's $t$-test was used to compare means for the dependent and independent samples.The null hypothesis was rejected when the error was equal to or less than 0.05 .

For the quantitative evaluation, protein concentrations were defined as either reduced or differentially expressed following comparison with the control group.

\section{Research ethics committee}

The study was approved by the Research Ethics Committee of the Faculdade de Medicina de Botucatu (UNESP), number 2.100.907, submission no. CAAE 21822813.9.0000.5411. Written informed consent for participation was given by the patient or parents.

\section{Results}

\section{Identification of differentially expressed proteins in $P$. brasiliensis and $P$. lutzii infections before treatment}

To identify the most abundant, differentially expressed proteins present in the serum of PCM patients caused by $P$. brasiliensis and P. lutzii, the samples were submitted to shotgun analysis, where all proteins were hydrolysed serially and subjected to the free-label analysis in a system liquid chromatography tandem MS (LC-MSMS). A total of 29 major proteins were detected and quantified. In the qualitative analysis, it was noted that the alpha-1-antichymotrypsin protein was not present in the control group (Table 2), but the immunoglobulin (Ig) alpha-2 chain $\mathrm{C}$ region was present only in the group of patients with PCM caused by P. lutzii (Table 2). The Ig heavy-chain V-III TIL was not present in patients with PCM caused by $P$. lut$z i i$ (Table 2), and CFB protein was not present in the group of patients with PCM caused by $P$. brasiliensis with relapse (Table 2). Finally, the alpha globin protein was not present in the group of patients with PCM caused by P. brasiliensis with relapse, nor was it present in the control group (Table 2).

To obtain information about the functions that were evident in the cellular proteome, the identified proteins were attributed to different biological processes and molecular functions, and they were localized to specific cells based on the biological evidence from the NCBI protein database and the Gene Ontology database. The classification of these 29 abundant proteins can be visualized in Fig 1; among the main categories are transport proteins, immunomodulatory proteins, 
Table 2. Qualitative analysis of serum proteins of patients with paracoccidioidomycosis, evaluated before treatment-G1, G2, G3 patients groups and healthy individuals-G4group.

\begin{tabular}{|c|c|c|c|c|c|c|c|}
\hline \multirow[t]{2}{*}{ Protein } & \multirow[t]{2}{*}{ Access code } & \multicolumn{2}{|c|}{$\begin{array}{l}\text { [G1] P. brasiliensis } \\
\text { with relapse }\end{array}$} & \multirow{2}{*}{$\begin{array}{c}\text { [G2] Patients with P. lutzii } \\
\begin{array}{c}\text { CF } \\
(n=4)\end{array}\end{array}$} & \multicolumn{2}{|c|}{$\begin{array}{c}\text { [G3] P. brasiliensis, } \\
\text { without relapse }\end{array}$} & \multirow{2}{*}{$\begin{array}{c}\text { [G4] Control } \\
\text { group } \\
(\mathbf{n}=\mathbf{3})\end{array}$} \\
\hline & & $\mathbf{A F}(\mathbf{n}=1)$ & $\mathrm{CF}(\mathrm{n}=2)$ & & $\operatorname{AF}(n=2)$ & $\mathrm{CF}(\mathrm{n}=2)$ & \\
\hline 1. Serum albumin & P02768.2 & + & + & + & + & + & + \\
\hline 2. Transferrin & P02787.3 & + & + & + & + & + & + \\
\hline 3. Apoliprotein A-I & P02647.1 & + & + & + & + & + & + \\
\hline 4. Haptoglobin & P00738.1 & + & + & + & + & + & + \\
\hline 5. Ig kappa chain C region & P01834.2 & + & + & + & + & + & + \\
\hline 6. Ig gamma-1 chain C region & P01857.1 & + & + & + & + & + & + \\
\hline 7. Ig lambda-2 chain C region & P0CG05.1 & + & + & + & + & + & + \\
\hline 8. Alpha-2-macroglobulin & P01023.3 & + & + & + & + & + & + \\
\hline 9. Ig alpha-1 chain C region & P01876.2 & + & + & + & + & + & + \\
\hline 10. Alpha-1-antitrypsin & P01009.3 & + & + & + & + & + & + \\
\hline 11. Hemopexin & P02790.2 & + & + & + & + & + & + \\
\hline 12. Ig gamma-2 chain $C$ region & P01859.2 & + & + & + & + & + & + \\
\hline 13. Alpha-1-acid-glycoprotein & P02763.1 & + & + & + & + & + & + \\
\hline 14. Complement C3 & P01024.2 & + & + & + & + & + & + \\
\hline 15. Apolipoprotein A-II & P02652.1 & + & + & + & + & + & + \\
\hline 16. Ig gamma-3 chain $C$ region & P01860.2 & + & + & + & + & + & + \\
\hline 17. Ig gamma-4 chain $C$ region & P01861.1 & + & + & + & + & + & + \\
\hline 18. Vitamin D-BindingProtein & P02774.1 & + & + & + & + & + & + \\
\hline 19. Ceruloplasmin & P00450.1 & + & + & + & + & + & + \\
\hline 20. Complement C4-A & P0C0L4.2 & + & + & + & + & + & + \\
\hline 21. Alpha-1-antichymotrypsin & P01011.2 & + & + & + & + & + & - \\
\hline 22. Kininogen & P01042.2 & + & + & + & + & + & + \\
\hline 23. Ig alpha-2 chain C region & P01877.3 & - & - & + & - & - & - \\
\hline 24. Beta-globin & P68871.2 & + & + & + & + & + & + \\
\hline 25. Ig kappa chain V-III & P04433.1 & + & + & + & + & + & + \\
\hline 26. Beta-2-glycoprotein 1 & P02749.3 & + & + & + & + & + & + \\
\hline 27. Ig heavy chain V-III TIL & P01764.2 & + & + & - & + & + & + \\
\hline 28. Complement factor B & P00751.2 & - & - & + & + & + & + \\
\hline 29. Alpha-globin & P69905.2 & - & - & + & + & + & - \\
\hline
\end{tabular}

+ present;-absent; AF-acute /subacute form; FC- chronic form and n- number of participants.

https://doi.org/10.1371/journal.pone.0202804.t002

and proteins that act to activate/regulate the complement system, those that activate the coagulation/protease-inhibition pathway, those that transport/metabolize lipids, and those that inhibit proteases and the extracellular matrix.

With respect to the quantitative analysis (Fig 2), statistically significant proteins with an adjusted $P$-value $<0.05$ (95\% confidence) were considered differentially expressed among the sample groups (Table 3) more information can be found in S1 Table. The results of transferrin (Table 3) in patients with PCM caused by P. brasiliensis were evaluated in patients with AF and the $\mathrm{CF}$ as a whole because there was no difference regarding the clinical form, as in patients with as without relapse.

The only difference observed in transferrin was a higher level in patients with PCM caused by $P$. lutzii than those caused by $P$. brasiliensis, without relapse (Table 3 ). 


\section{A}

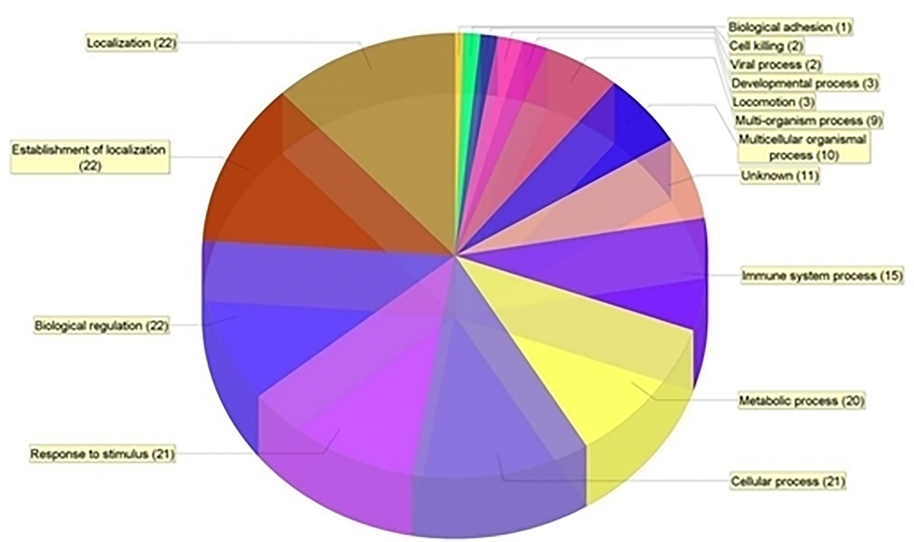

Biological adhesion - Cell killing - Viral process - Developmental process - Locomotion - Mult-organism process - Multicellular organismal process - Unknown -Immune system process Metabolic process - Cellular process - Response to stimulus - Biological regulation - Establishment of localization - Localization

B

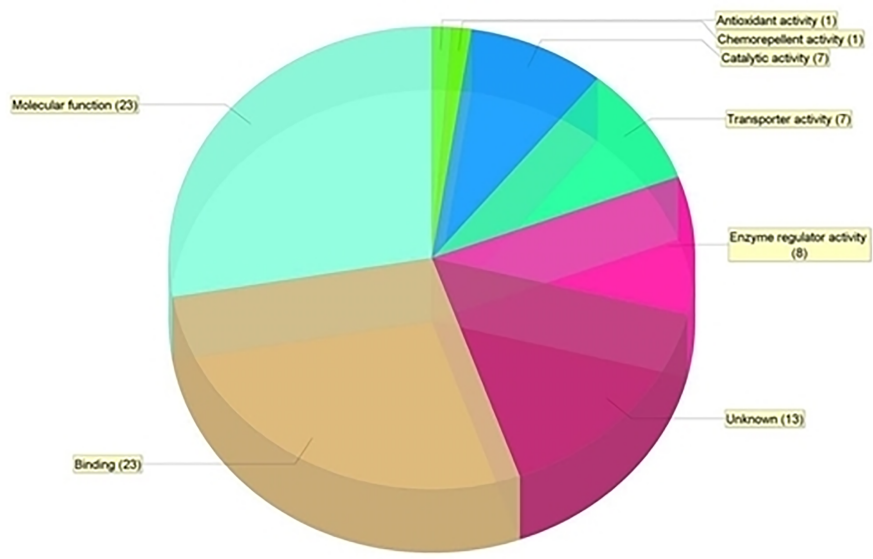

Antioxidant activity - Chemorepellent activity - Catalytic activity - Transporter activity - Enzyme regulator activity - Unknown - Binding - Molecular function C

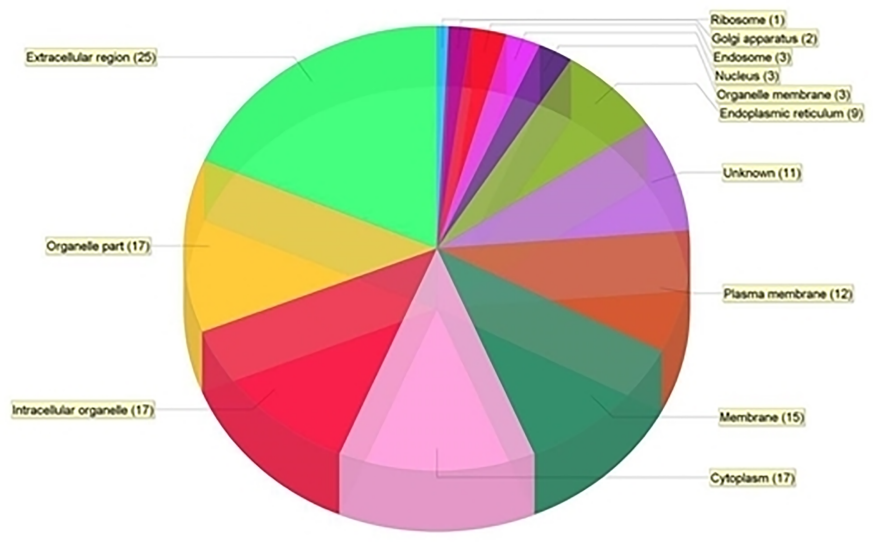

-Ribosome · Golgi apparatus - Endosome · Nucleus · Organelle membrane - Endoplasmic reticulum · Unknown - Plasma membrane · Membrane · Cyloplasm - Intracellular organelle - Organellle part - Extracellular region 
Fig 1. Classification of abundant proteins present in the human blood serum in infections of $P$. brasiliensis and $P$. lutzii before treatment according to their participation in a A) biological function, B) molecular function and C) cell components. The classification of proteins was analyzed by the STRING software according to the annotations deposited in the Gene Ontology database.

https://doi.org/10.1371/journal.pone.0202804.g001

However, the gamma-2 chain C region and apolipoprotein A-II Ig proteins showed reduced expression in the group of relapsed patients with PCM caused by P. brasiliensis, in relation to the control group (Table 3).

In this STRING analysis (Fig 3), a strong interaction among the Ig alpha-2-chain $\mathrm{C}$ region (IGLL1), the Ig gamma-2-chain C region (IGLL5), and the Ig heavy-chain VIII TIL (ENS0 00223931) was observed. In addition, interactions among transferrin (TF), apoliprotein A-II (APOA2), alpha-1-antichytrypsin (SERPINA3), CFB, and alpha-globin (HBA1) proteins were also observed.

\section{Discussion}

The proteomic methodology has been used for the identification of many agents of infectious diseases, such as bacteria $[17,18]$, protozoa $[19,20]$ and fungi [21-24]. Some proteomic studies have been performed to identify Paracoccidioides spp. isolates regarding its species [7, 13, $25,26]$. All these studies focused proteins from the etiological agents, and none of them analyzed protein froms serum samples of the patients.

Some studies have used two-dimensional electrophoresis and mass spectrometry to isolate and identify proteins to be useful in the diagnosis and monitoring of treatment in Candida albincans [21,22], Cryptococcus gatti [24] and Aspergillus fumigatus [23].

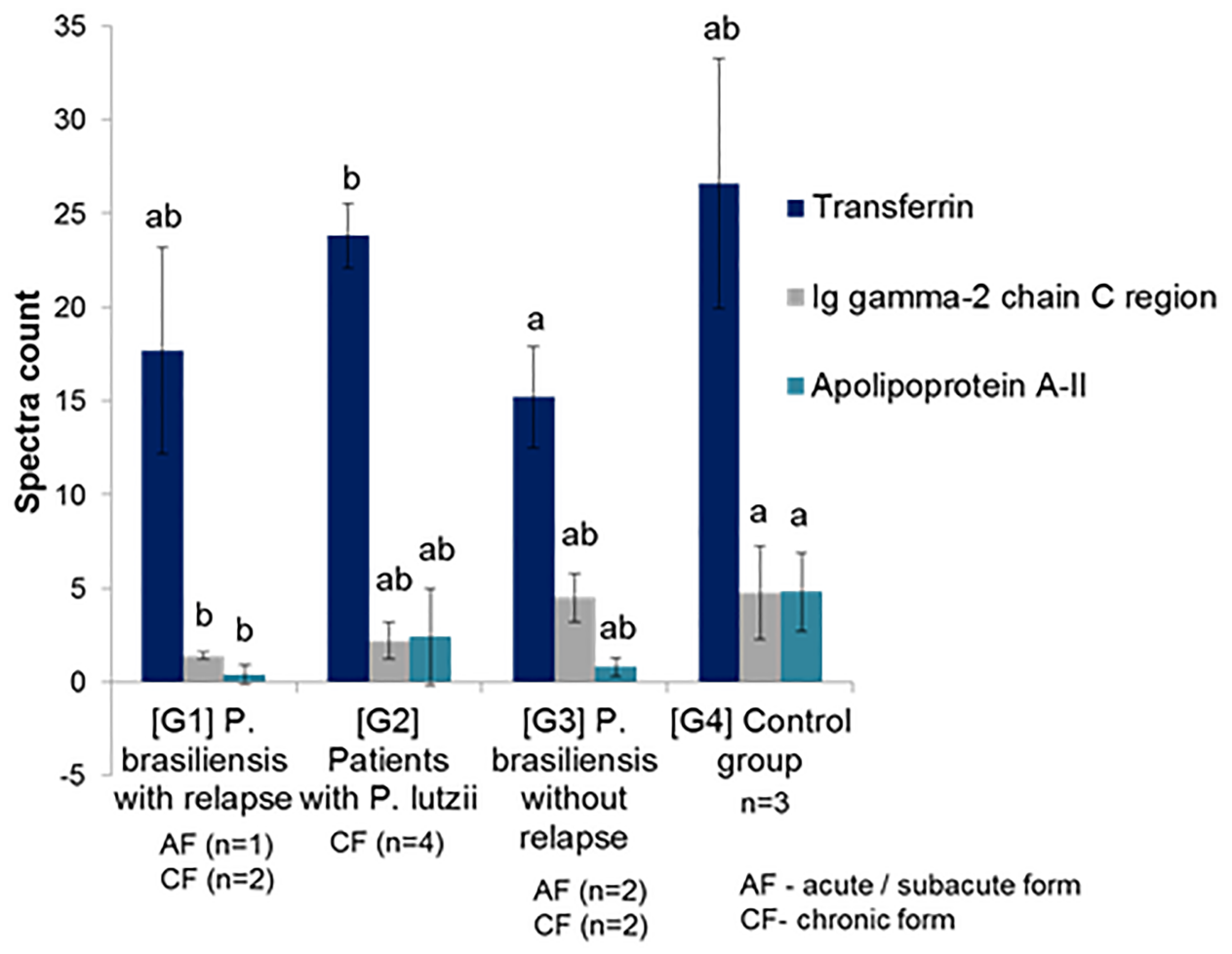

Fig 2. Comparison of serum proteins, presented as mean and standard deviation in patients with paracoccidioidomycosis, evaluated before treatment-G1, G2, G3 patients groups and healthy individuals-G4 group.

https://doi.org/10.1371/journal.pone.0202804.g002 
Table 3. Quantification of serum proteins by spectral counting, presented as mean and standard deviation in patients with paracoccidioidomycosis, evaluated before treatment-G1, G2, G3 patients groups and healthy individuals-G4 group.

\begin{tabular}{|c|c|c|c|c|c|c|c|c|c|}
\hline Protein & $\begin{array}{l}\text { Access } \\
\text { code }\end{array}$ & $\begin{array}{c}\text { Molecular } \\
\text { mass } \\
(\mathrm{kDa})\end{array}$ & $\begin{array}{c}\text { Coverage } \\
\text { rate } \\
(\%)\end{array}$ & $\begin{array}{c}{[\mathrm{G} 1] P .} \\
\text { brasiliensis } \\
\text { with relapse } \\
\mathrm{AF}(\mathrm{n}=1) / \mathrm{CF} \\
(\mathrm{n}=2)\end{array}$ & $\begin{array}{c}\text { [G2] Patients with } \\
\text { P. lutzii } \\
\text { CF }(n=4)\end{array}$ & $\begin{array}{c}{[\mathrm{G} 3] \mathrm{P} .} \\
\text { brasiliensis } \\
\text { without relapse } \\
\text { AF }(\mathrm{n}=2) / \mathrm{CF} \\
(\mathrm{n}=2)\end{array}$ & $\begin{array}{l}\text { [G4] Control } \\
\text { group } \\
(\mathbf{n}=3)\end{array}$ & Main function & $p$ \\
\hline 1. Serum albumin & P02768.2 & 69 & 79 & $127.0 \pm 48.9$ & $167.8 \pm 23.4$ & $140.1 \pm 23.5$ & $197.1 \pm 16.1$ & Transport & 0.06 \\
\hline 2. Transferrin & P02787.3 & 77 & 34 & $17.7 \pm 5.5 \mathrm{ab}$ & $23.8 \pm 1.7 \mathrm{~b}$ & $15.2 \pm 2.7 \mathrm{a}$ & $26.6 \pm 6.7 \mathrm{ab}$ & Transport & 0.02 \\
\hline 3. Apoliprotein A-I & P02647.1 & 31 & 36 & $9.11 \pm 9.5$ & $18.3 \pm 9.8$ & $13.7 \pm 3.5$ & $23.5 \pm 3.6$ & Transport & 0.14 \\
\hline 4. Haptoglobin & P00738.1 & 45 & 14 & $14.0 \pm 1.4$ & $15.1 \pm 12.4$ & $24.9 \pm 6.3$ & $12.5 \pm 5.1$ & Immunomodulatory & 0.21 \\
\hline $\begin{array}{l}\text { 5. Ig kappa chain C } \\
\text { region }\end{array}$ & P01834.2 & 12 & $\cdots$ & $9.5 \pm 4.5$ & $16.2 \pm 1.1$ & $18.9 \pm 9.1$ & $18.0 \pm 1.6$ & Immunomodulatory & 0.19 \\
\hline $\begin{array}{l}\text { 6. Ig gamma-1 chain C } \\
\text { region }\end{array}$ & P01857.1 & 36 & $\cdots$ & $9.6 \pm 4.8$ & $11.5 \pm 2.0$ & $12.9 \pm 5.6$ & $8.2 \pm 1.58$ & Immunomodulatory & 0.47 \\
\hline $\begin{array}{l}\text { 7. Ig lambda-2 chain } C \\
\text { region }\end{array}$ & P0DOY2 & 11 & 75 & $8.0 \pm 5.1$ & $9.6 \pm 4.4$ & $13.5 \pm 6.6$ & $9.7 \pm 3.6$ & Immunomodulatory & 0.54 \\
\hline $\begin{array}{l}\text { 8. Alpha- } \\
\text { 2-macroglobulin }\end{array}$ & P01023.3 & 163 & 05 & $5.4 \pm 3.6$ & $15.9 \pm 4.1$ & $8.3 \pm 5.9$ & $9.3 \pm 4.4$ & $\begin{array}{l}\text { Activate/regulate the complement } \\
\text { system }\end{array}$ & 0.07 \\
\hline $\begin{array}{l}\text { 9. Ig alpha-1 chain } C \\
\text { region }\end{array}$ & P01876.2 & 38 & 29 & $7.2 \pm 2.1$ & $8.5 \pm 2.3$ & $11.2 \pm 3.02$ & $10.1 \pm 2.0$ & Immunomodulatory & 0.22 \\
\hline 10. Alpha-1-antitrypsin & P01009.3 & 47 & 08 & $3.3 \pm 3.1$ & $5.2 \pm 1.6$ & $9.0 \pm 2.2$ & $5.1 \pm 3.6$ & $\begin{array}{l}\text { Activate the coagulation/protease- } \\
\text { inhibition pathway }\end{array}$ & 0.08 \\
\hline 11. Hemopexin & $\mathrm{P} 02790.2$ & 52 & 19 & $3.1 \pm 4.0$ & $5.4 \pm 2.9$ & $5.5 \pm 2.2$ & $8.6 \pm 3.0$ & Transport & 0.23 \\
\hline $\begin{array}{l}\text { 12. Ig gamma-2 chain } C \\
\text { region }\end{array}$ & P01859.2 & 36 & 29 & $1.4 \pm 1.2 \mathrm{~b}$ & $2.2 \pm 1.0 \mathrm{ab}$ & $4.5 \pm 1.3 \mathrm{ab}$ & $4.78 \pm 2.5 \mathrm{a}$ & Immunomodulatory & 0.04 \\
\hline $\begin{array}{l}\text { 13. Alpha-1-acid- } \\
\text { glycoprotein }\end{array}$ & P02763.1 & 24 & 19 & $2.6 \pm 3.0$ & $3.3 \pm 3.2$ & $4.9 \pm 2.1$ & $3.6 \pm 1.5$ & Transport & 0.71 \\
\hline 14. Complement C3 & P01024.2 & 187 & 05 & $1.1 \pm 1.1$ & $4.5 \pm 4.0$ & $2.0 \pm 1.2$ & $4.7 \pm 3.7$ & Immunomodulatory & 0.34 \\
\hline 15. Apolipoprotein A-II & P02652.1 & 11 & 58 & $0.4 \pm 0.5 b$ & $2.4 \pm 2.6 \mathrm{ab}$ & $0.8 \pm 0.5 \mathrm{ab}$ & $4.8 \pm 2.1 \mathrm{a}$ & Transport/metabolize lipids & 0.04 \\
\hline $\begin{array}{l}\text { 16. Ig gamma-3 chain } C \\
\text { region }\end{array}$ & P01860.2 & 41 & $\cdots$ & $0.8 \pm 1.2$ & $2.0 \pm 1.1$ & $0.8 \pm 0.6$ & $1.7 \pm 1.0$ & Immunomodulatory & 0.34 \\
\hline $\begin{array}{l}\text { 17. Ig gamma-4 chain } C \\
\text { region }\end{array}$ & P01861.1 & 36 & 23 & $2.8 \pm 5.0$ & $1.3 \pm 1.6$ & $3.7 \pm 5.1$ & $0.8 \pm 1.5$ & Immunomodulatory & 0.73 \\
\hline $\begin{array}{l}\text { 18. Vitamin D-Binding } \\
\text { Protein }\end{array}$ & $\mathrm{P} 02774.1$ & 53 & 05 & $0.2 \pm 0.3$ & $1.0 \pm 1.5$ & $0.7 \pm 0.6$ & $1.6 \pm 0.5$ & Immunomodulatory & 0.39 \\
\hline 19. Ceruloplasmin & P00450.1 & 122 & 01 & $0.0 \pm 0.0$ & $1.1 \pm 0.6$ & \pm 1.1 & $0.1 \pm 0.1$ & Transport & 0.08 \\
\hline 20. Complement C4-A & P0C0L4.2 & 193 & 01 & $0.2 \pm 0.3$ & $0.3 \pm 0.4$ & $0.5 \pm 0.9$ & $1.0 \pm 0.9$ & Immunomodulatory & 0.46 \\
\hline $\begin{array}{l}\text { 21. Alpha- } \\
\text { 1-antichymotrypsin }\end{array}$ & P01011.2 & 48 & 02 & $0.2 \pm 0.3$ & $0.5 \pm 1.1$ & $0.6 \pm 0.2$ & $0.0 \pm 0.0$ & $\begin{array}{l}\text { protease-inhibition pathway/ } \\
\text { metabolize lipids }\end{array}$ & 0.56 \\
\hline 22. Kininogen & P01042.2 & 72 & 02 & $0.1 \pm 0.1$ & $0.5 \pm 0.6$ & $0.1 \pm 0.1$ & $0.2 \pm 0.3$ & protease-inhibition pathway & 0.60 \\
\hline $\begin{array}{l}\text { 23. Ig alpha-2 chain } C \\
\text { region }\end{array}$ & P01877.3 & 37 & 08 & $0.0 \pm 0.0$ & $0.1 \pm 0.3$ & $0.0 \pm 0.0$ & $0.0 \pm 0.0$ & Immunomodulatory & 0.52 \\
\hline 24. Beta-globin & P68871.2 & 16 & 09 & $0.3 \pm 0.5$ & $2.1 \pm 2.0$ & $0.5 \pm 1.0$ & $0.3 \pm 0.3$ & Transport & 0.22 \\
\hline 25. Ig kappa chain V-III & P04433.1 & 13 & 08 & $0.2 \pm 0.3$ & $0.8 \pm 0.5$ & $0.7 \pm 1.5$ & $0.3 \pm 0.5$ & Immunomodulatory & 0.78 \\
\hline $\begin{array}{l}\text { 26. Beta-2-glycoprotein } \\
1\end{array}$ & P02749.3 & 38 & 15 & $0.1 \pm 0.1$ & $0.6 \pm 0.4$ & $0.3 \pm 0.6$ & $0.8 \pm 0.1$ & Extracellular matrix & 0.22 \\
\hline $\begin{array}{l}\text { 27. Ig heavy chain V-III } \\
\text { TIL }\end{array}$ & $\mathrm{P} 01764.2$ & 12 & 26 & $0.3 \pm 0.5$ & $0.0 \pm 0.0$ & $1.4 \pm 2.2$ & $0.1 \pm 0.1$ & Immunomodulatory & 0.41 \\
\hline $\begin{array}{l}\text { 28. Complement factor } \\
\text { B }\end{array}$ & P00751.2 & 86 & 01 & $0.0 \pm 0.0$ & $0.5 \pm 0.6$ & $0.4 \pm 0.4$ & $0.5 \pm 0.5$ & Immunomodulatory & 0.49 \\
\hline 29. Alpha-globin & P69905.2 & 15 & 11 & $0.0 \pm 0.0$ & $0.5 \pm 0.6$ & $0.1 \pm 0.1$ & $0.0 \pm 0.0$ & Transport & 0.24 \\
\hline
\end{tabular}

Small letters compare values in the same row. The same letter indicates means that do not differ from each other, while different letters indicate statistically significant differences $(\mathrm{p} \leq 0.05)$; $\mathrm{AF}$-acute / subacute form; CF- chronic form and $\mathrm{n}$ - number of participants.

https://doi.org/10.1371/journal.pone.0202804.t003 


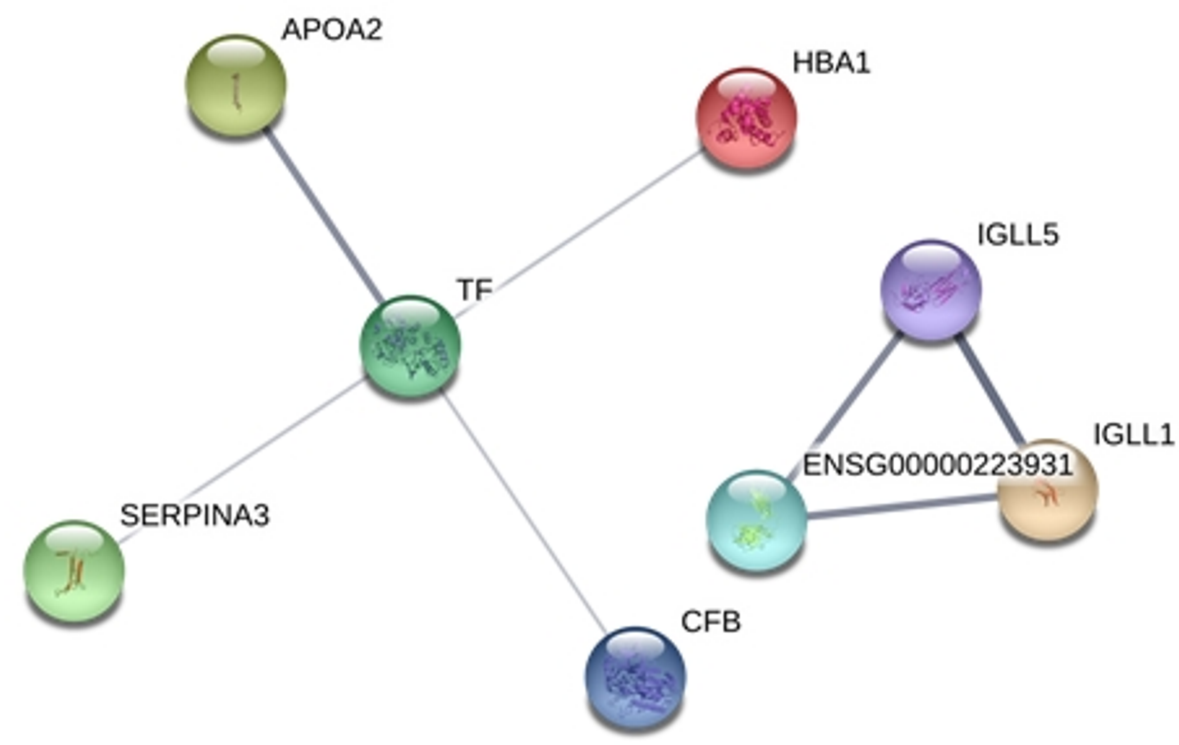

Fig 3. Interaction network between the 8 proteins differential expressed in infections of $P$. brasiliensis and $P$. lutzii before treatment. The stronger associations are represented by thicker lines. The protein network was analyzed using STRING software. TF: transferrin, APOA2: Apoliprotein A-II, SERPINA3: alpha-1-antichytrypsin, CFB: complement factor $\mathrm{B}$ and HBA1: alpha-globin, IGLL1: Ig alpha-2-chain $\mathrm{C}$ region, IGLL5: Ig gamma-2-chain $\mathrm{C}$ region and ENS000223931: Ig heavy chain V-III TIL.

https://doi.org/10.1371/journal.pone.0202804.g003

PCM is a systemic granulomatous disease that, in spite of an appropriate treatment, can present late relapse due to the persistence of latent fungi. There are two problems to be considered: 1) What would be the best marker to differentiate the proteins caused by $P$. brasiliensis from those produced by P. lutzii? 2) At admission, is it possible to detect the biomarker for a late relapse?

Human serum contains a large number of proteins, classified in relationship to their functions as transporters, immunomodulators, activators, and regulators of the complement system; activators of the coagulation pathway; and as protease inhibitors and lipid metabolism and matrix proteins. Several proteins perform more than one of these functions. These proteins, as well as tissue molecules, can be used in the diagnosis and monitoring of therapy [27]. Although 1,175 proteins have been described in human plasma [28], only 10 of them constitute $95 \%$ of the total protein content [29, 30]: albumin (54\%); IgG (alpha-1-antitrypsin; 3.8\%); alpha-2-macroglobulin (3.6\%), IgA (3.5\%); transferrin (3.3\%); haptoglobin (3\%); apolipoprotein A-1 (3\%);IgM (2\%); and alpha-1 acid glycoprotein (1.3\%).

The analysis of patient serum samples drawn at admission revealed the presence of the alpha-1-antichymotrypsin protein (SERPINA 3) in patients with active PCM, with no quantitative difference among those caused by $P$. brasiliensis, either with or without subsequent relapse, and those by $P$. lutzii. Since alpha-1-antichymotrypsin (SERPINA 3), a protease inhibitor protein that acts on lipid metabolism, is present during inflammatory processes, including those of infectious etiology, these findings corroborate those of the literature [31].

The complement factor B (CFB) is part of the complement system, which is composed of plasma membrane proteins and soluble proteins in blood; these proteins participate in the innate and acquired defenses by opsonizing pathogens and inducing an appropriate series of inflammatory responses. In PCM patients, the contact between the yeast cells and the phagocytes is facilitated by the activation of the alternative pathway of the complement system, which leads to its opsonization [32]. In addition, the fungus itself, including the $43 \mathrm{kDa}$ 
glycoprotein (gp43), which is considered the main antigen secreted by P. brasiliensis, can promote the initial adhesion and internalization of the yeast by phagocytic cells [33]. The results revealed that CFB was not identified in the serum of patients who had relapsed, suggesting that the absence of this marker on admission might be predictive of relapse.

Alpha globin (HBA1), a component of the hemoglobin [34], was not identified at admission in patients who later relapsed, such as the CFB. However, HBA1 differs from CBF insofar as it was not identified in the control group.

The Ig alpha- 2 chain $\mathrm{C}$ region (IGLL1) is an immunomodulatory protein that constitutes the major class of immunoglobulins present in body secretions. It acts against local infection and it also blocks the access of foreign antigens to the general immune system [35]. The identification of this protein only in serum from patients infected with P. lutzii suggests that IGLL1 could be a biomarker of this etiology. It is worth mentioning that this protein was not identified in control sera.

The heavy-chain Ig V-III TIL (ENS000223931), which participates in antigen recognition [36], was not identified in the serum of patients infected by $P$. lutzii, but it was present in those with PCM caused by P. brasiliensis and in the control group. Thus, the absence of this antigen suggest the presence of PCM caused by P. lutzii.

Transferrin (TF) is a glycoprotein constituted by a single polypeptide chain and its main function is to transport iron through plasma [37]. Serum TF levels were lower in samples from PCM patients than from those in the control group. Since the fungi of the genus Paracoccidioides consume iron [10,38,39], our findings confirm those of previous works; however, no differences in TF serum levels were observed among PCM patients from the three groups.

The Ig gamma-2 chain $\mathrm{C}$ region (IGLL5) revealed, at admission, a TF-like behavior, whereby IGLL5 presented lower values than those observed in healthy controls. However, different from what was observed for TF, IGLL5 was present in lower levels in relapsed P. brasiliensis patients than in the unrelapsed ones. It also appeared in lower levels among those infected by $P$. lutzii. These findings suggest that patients with very low TF serum levels may relapse.

The strong interaction observed among the Ig alpha-2-chain C region (IGLL1), the Ig gamma-2-chain C region (IGLL5), and the Ig heavy-chain VIII TIL (ENS000223931) was expected because they are proteins of the immune system, active as a defensive barrier against infectious conditions.

The proteomic assay was used to evaluate more than 20 proteins in the same analysis, aiming to use a proteomic approach to identify proteins that could differentiate infections caused by $P$. brasiliensis from those produced by $P$. lutzii, as well as to identify a biomarker that could predict patients prone to relapse. It is well known that this methodology could not be standardized in the clinical laboratories. Thus, the next step of this research is the evaluation of the selected proteins using commercial kits. A higher number of patients will be evaluated, and the selections of serum samples are ongoing.

This is the first time the proteomic methodology was performed in serum samples to identify biomarkers for infectious diseases. These findings, evaluated at patient's admission, indicate that the presence of IGLL1 and the absence of heavy-chain V-III TIL Ig (ESP000223931) are indicators of $P$. lutzii infection. Moreover, the absence of CFB at admission may be a predictor of relapse.

\section{Supporting information}

S1 Table. (A) Quality control of proteomic data by protein identification probability, presented as average in patients with paracoccidioidomycosis, evaluated before treatment- 
G1, G2, G3 patients groups and healthy individuals-G4 group. AF-acute / subacute form; CF- chronic form; n- number of participants; ... sequence not in database. (B) Quality control of proteomic data by protein identification probability, presented as average in patients with paracoccidioidomycosis, evaluated before treatment-G1, G2, G3 patients groups and healthy individuals-G4 group. AF-acute / subacute form; CF- chronic form; n- number of participants; ... sequence not in database. (C) Quality control of proteomic data by protein identification probability, presented as average in patients with paracoccidioidomycosis, evaluated before treatment-G1, G2, G3 patients groups and healthy individuals-G4 group. AF-acute / subacute form; CF- chronic form; $n$ - number of participants; ... sequence not in database.

(PDF)

\section{Author Contributions}

Conceptualization: Tatiane Fernanda Sylvestre, Rinaldo Poncio Mendes.

Data curation: Tatiane Fernanda Sylvestre, Ricardo de Souza Cavalcante, Anamaria Mello Miranda Paniago, Rinaldo Poncio Mendes.

Formal analysis: Tatiane Fernanda Sylvestre, Rinaldo Poncio Mendes.

Funding acquisition: Tatiane Fernanda Sylvestre, Rinaldo Poncio Mendes.

Investigation: Tatiane Fernanda Sylvestre, Rinaldo Poncio Mendes.

Methodology: Tatiane Fernanda Sylvestre, Julhiany de Fátima da Silva, Simone Schneider Weber, Bianca Alves Pauletti, Lídia Raquel de Carvalho, Lucilene Delazari dos Santos, Rinaldo Poncio Mendes.

Project administration: Tatiane Fernanda Sylvestre, Rinaldo Poncio Mendes.

Resources: Tatiane Fernanda Sylvestre, Rinaldo Poncio Mendes.

Software: Tatiane Fernanda Sylvestre, Rinaldo Poncio Mendes.

Supervision: Tatiane Fernanda Sylvestre, Rinaldo Poncio Mendes.

Validation: Tatiane Fernanda Sylvestre, Rinaldo Poncio Mendes.

Visualization: Tatiane Fernanda Sylvestre, Rinaldo Poncio Mendes.

Writing - original draft: Tatiane Fernanda Sylvestre, Ricardo de Souza Cavalcante, Julhiany de Fátima da Silva, Anamaria Mello Miranda Paniago, Simone Schneider Weber, Bianca Alves Pauletti, Lídia Raquel de Carvalho, Lucilene Delazari dos Santos, Rinaldo Poncio Mendes.

Writing - review \& editing: Tatiane Fernanda Sylvestre, Rinaldo Poncio Mendes.

\section{References}

1. Teixeira MM, Theodoro RC, Carvalho MJA, Fernandes L, Paes HC, Hahn RC, et al. Phylogenetic analysis reveals a high level of speciation in the Paracoccidioides genus. Mol Phylo Evol. 2009; 52: 273283. https://doi.org/10.1016/j.ympev.2009.04.005 PMID: 19376249

2. Restrepo A. The ecology of Paracoccidioides brasiliensis: a puzzle still unsolved. Sabouraudia. J Med Vet Mycol. 1985; 23: 323-334.

3. Marques SA, Franco MF, Mendes RP, Silva NCA, Baccili C, Curcelli ED, et al. Aspectos epidemiológicos da paracoccidioidomicose na área endêmica de Botucatu (São Paulo-Brasil). Rev Inst Med Trop São Paulo. 1983; 25: 87-92. PMID: 6622920 
4. Batista J Jr, Camargo ZP, Fernandes GF, Vicentini AP, Fontes CJF, Hahn RC. Is the geographical origin of a Paracoccidioides brasiliensis isolate important for antigen production for regional diagnosis of paracoccidioidomycosis? Mycoses. 2008; 53: 176-180. https://doi.org/10.1111/j.1439-0507.2008. 01687.x PMID: 19422525

5. Vidal MSM, Del Negro GMB, Vicentini AP, Svidzinski TIE, Mendes-Giannini MJ, Almeida AMF, et al. Serological diagnosis of paracoccidioidomycosis: high rate of inter-laboratorial variability among Medical Mycology Reference Centers. PLoS Negl Trop Dis. 2014; 8: e3174. https://doi.org/10.1371/journal. pntd.0003174 PMID: 25211336

6. Gegembauer G, Araujo LM, Pereira EF, Rodrigues AM, Paniago AMM, Hahn RC, et al. Serology of paracoccidioidomycosis due to Paracoccidioides lutzii. PLoS Negl Trop Dis. 2014; 8: 7. e2986. https:// doi.org/10.1371/journal.pntd.0002986 PMID: 25032829

7. Sylvestre TF, Silva LRF, Cavalcante RS, Moris DV, Venturini J, Vicentini AP, et al. Prevalence and serological diagnosis of relapse in paracoccidioidomycosis patients. PLoS Negl Trop Dis. 2014; 8: 5. e2834. https://doi.org/10.1371/journal.pntd.0002834 PMID: 24787147

8. Castilho DG, Chaves AF, Xander P, Zelanis A, Kitano ES, Serrano SM, et al. Exploring potential virulence regulators in Paracoccidioides brasiliensis isolates of varying virulence through quantitative proteomics. J Proteome Res. 2014; 13: 4259-4271. https://doi.org/10.1021/pr5002274 PMID: 25145636

9. Rezende $T C$, Borges $C L$, Magalhães $A D$, de Sousa MV, Ricart CA, Bailão $A M$, et al. A quantitative view of the morphological phases of Paracoccidioides brasiliensis using proteomics. J Proteomics. 2011; 75: 572-587. https://doi.org/10.1016/j.jprot.2011.08.020 PMID: 21920475

10. Parente AFA, Bailão AM, Borges CL, Parente JA, Magalhães AD, Ricart CAO, et al. Proteomic analysis reveals that iron availability alters the metabolic status of the pathogenic fungus Paracoccidioides brasiliensis. PLoS ONE. 2011; 6: 7. e22810. https://doi.org/10.1371/journal.pone.0022810 PMID: 21829521

11. Casaletti L, Lima PS, Oliveira LN, Borges CL, Báo SN, Bailão A.M, et al. Analysis of Paracoccidioideslutzii mitochondria: a proteomic approach. Yeast. 2017; 34: 179-188. https://doi.org/10.1002/yea. 3225 PMID: 27886402

12. Mendes RP, Cavalcante RS, Marques SA, Marques MEA, Venturini J, Sylvestre TF, et al. Paracoccidioidomycosis: Current Perspectives from Brazil. Open Microbiol J. 2017; 11: 224-282. https://doi.org/ 10.2174/1874285801711010224 PMID: 29204222

13. Camargo ZP, Berzaghi R, Amaral CC, Silva SH. Simplified method for producing Paracoccidioides brasiliensis exoantigens for use in immunodiffusion tests. Med Mycol. 2003; 41: 539-542. PMID: 14725330

14. Mendes RP. "The gamut of clinical manifestations" in: Franco M, Lacaz CS, Restrepo-Moreno A, Del Negro G. Paracoccidioidomycosis. (Boca Raton: CRC Press), 1994; 233-258.

15. Bradford MM. A rapid and sensitive method for the quantitation of microgram quantities of protein utilizing the principle of protein-dye binding. Anal Biochem. 1976; 72: 248-254. https://doi.org/10.1016/ 0003-2697(76)90527-3 PMID: 942051

16. Aragão AZB, Belloni M, Simabuco FM, Zanetti MR, Yokoo S, Domingues RR, et al. Novel processed form of Syndecan-1 shed from SCC-9 cells plays a role in cell migration. PLoS ONE. 2012; 7: 8. e43521. https://doi.org/10.1371/journal.pone.0043521 PMID: 22905270

17. Otto A, van Dijl JM, Hecker M, Becher D. The Staphylococcus aureus proteome. Int J Med Microbiol. 2014; 304(2):110-20. https://doi.org/10.1016/j.jimm.2013.11.007 PMID: 24439828

18. Mailhac A, Durand H, Boisset S, Maubon D, Berger F, Maurin M, et al. MALDI-TOF mass spectrometry for rapid diagnosis of postoperative endophthalmitis. J Proteomics. 2017; 30: 150-52. https://doi.org/ 10.1016/j.jprot.2016.10.017

19. Del Chierico F, Di Cave D, Accardi C, Santoro M, Masotti A, D'Alfonso R, et al. Identification and typing of free-living Acanthamoeba spp. by MALDI-TOF MS Biotyper. Exp Parasitol. 2016; 170: 82-9. https:// doi.org/10.1016/j.exppara.2016.09.007 PMID: 27663468

20. Singh P, Mirdha BR, Srinivasan A, Rukmangadachar LA, Singh S, Sharma $P$, et al. Identification of invasion proteins of Cryptosporidium parvum. World J Microbiol Biotechnol. 2015; 31(12): 1923-34. https://doi.org/10.1007/s11274-015-1936-9 PMID: 26492887

21. Pitarch A, Abian J, Carrascal M, Sánchez M, Nombela C, Gil C. Proteomics-based identification of novel Candida albicans antigens for diagnosis of systemic candidiasis in patients with underlying hematological malignancies. Proteomics. 2004; 4: 2084-3106.

22. Martins LMS, Andrade HM, Vainstein MH, Wanke B, Schrank A, Balaguez CB, et al. Immunoproteomic and immunoinformatics analysis of Cryptococcus gatti: novel candidate antigens for diagnosis. Future Microbiol. 2013; 8(4): 549-63. https://doi.org/10.2217/fmb.13.22 PMID: 23534365 
23. Virginio ED, Kubitschek-Barreira PH, Batista MV, Schirmer MR, Abdelhay E, Shikanai-Yasuda MA, et al. Immunoproteome of Aspergillus fumigatus using sera of patients with invasive aspergillosis. Int $\mathrm{J}$ Mol Sci. 2014; 15: 14505-30. https://doi.org/10.3390/ijms150814505 PMID: 25141105

24. Brandão MSS, Martins LMS, Andrade HM, Faria AR, Leal MJS, Silva AS, et al. Immunoreactivity of synthetic peptides derived from proteins of Cryptococcus gattii. Future Microbiol. 2014; 9(7): 871-78. https://doi.org/10.2217/fmb.14.49 PMID: 25156376

25. Jantsch J, Chakravortty D, Turza N, Prechtel AT, Buchholz B, Gerlach RG, et al. Hypoxia and hypoxiainducible factor-1 alpha modulate lipopolysaccharide-induced dendritic cell activation and function. $J$ Immunol. 2008; 180: 4697-4705. https://doi.org/10.4049/jimmunol.180.7.4697 PMID: 18354193

26. Weidemann A, Johnson RS. Biology of HIF-1alpha. Cell Death Differ. 2008; 15: 621-27. https://doi. org/10.1038/cdd.2008.12 PMID: 18259201

27. Anderson NL, and Anderson NG. The human plasma proteome: history, character, and diagnostic prospects. Mol Cell Proteomics. 2002; 1: 845-867. https://doi.org/10.1074/mcp.R200007-MCP200 PMID: 12488461

28. Anderson NL, Polanski M, Pieper R, Gatlin T, Tirumalai RS, Conrads TP, et al. The human plasma proteome: a nonredundant list developed by combination of four separate sources. Mol Cell Proteomics. 2004; 3: 311-326. https://doi.org/10.1074/mcp.M300127-MCP200 PMID: 14718574

29. Putnam FR. "Alpha, beta, gamma, omega-the structure of the plasma protein" in: Putmam FR. The plasma proteins: structure, function and genetic control. (Orlando: Academic Press). 1984; 2: 45-146.

30. Pieper R, Su Q, Gatlin CL, Huang ST, Anderson NL, Steiner S. Multi-component immunoaffinity subtraction chromatography: an innovative step towards a comprehensive survey of the human plasma proteome. Proteomics. 2003; 3: 422-432. https://doi.org/10.1002/pmic.200390057 PMID: 12687610

31. Kalsheker N. Alpha 1-antichymotrypsin. Int J Biochem Cell Biol. 1996; 28: 961-964. https://doi.org/10. 1016/1357-2725(96)00032-5 PMID: 8930118

32. Shikanai-Yasuda MA, Assis CM, Takeda KM, Tamashiro N, Bueno JP. Monocyte adherence to Paracoccidioides brasiliensis, zymosan-C3b and erythrocyte-hemolysin in patients with paracoccidioidomycosis. Mycopathologia. 1997; 138: 65-69. PMID: 9433808

33. Almeida SR, Unterkircher CS, Camargo ZP. Involvement of the major glycoprotein (gp43) of Paracoccidioidesbrasiliensis in attachment to macrophages. Med Mycol. 1998; 36: 405-411. PMID: 10206751

34. Ribeiro DM, and Sonati MF. Regulação da expressão do gene da alfa-globina humana e alfa-talassemia. Genet Mol Res. 2008; 7: 1045-1053. PMID: 19048483

35. Kerr MA. The structure and function of human IgA. Biochem J. 1990; 271: 185-196.

36. Wang AC, Wang IY, Fudenberg HH. Immunoglobulin structure and genetics. Identity between variable regions of a mu and a gamma2 chain. J Biol Chem. 1977; 252: 7192-7199. PMID: 409716

37. Andrés MT, and Fierro JF. Antimicrobial mechanism of action of transferrins: selective inhibition of $\mathrm{H}$ +-ATPase. Antimicrob Agents Chemother. 2010; 54: 4335-4342. https://doi.org/10.1128/AAC.0162009 PMID: 20625147

38. Dias-Melicio LA, Moreira AP, Calvi SA, Soares AM. Chloroquine inhibits Paracoccidioides brasiliensis survival within human monocytes by limiting the availability of intracellular iron. Microbiol Immunol. 2006; 50: 307-314. https://doi.org/10.1111/j.1348-0421.2006.tb03798.x PMID: 16625052

39. Arango R, and Restrepo A. Growth and production of iron chelants by Paracoccidioides brasiliensis mycelial and yeast forms. J Med Vet Mycol. 1988; 26: 113-118. https://doi.org/10.1080/ 02681218880000161 PMID: 3418467 